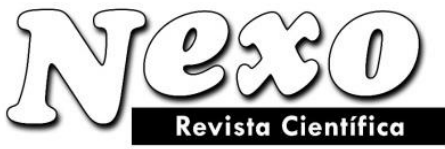

ISSN-E 1995-9516

Universidad Nacional de Ingeniería COPYRIGHT @ (UNI). TODOS LOS DERECHOS RESERVADOS

http://revistas.uni.edu.ni/index.php/Nexo

https://doi.org/10.5377/nexo.v33i02.10793

\title{
Innovation Management in the Supply Chains of Russian Natural Gas, Taking into Account the Regional Structure of its Production
}

\section{Gestión de la innovación en las cadenas de suministro de gas natural ruso, teniendo en cuenta la estructura regional de su producción}

\author{
Beilin Igor Leonidovich
}

Associate Professor of the Department of Territorial Economics of the Institute of Management, Economics and Finance, Kazan Federal University, Tatar Scientific Research Institute of Agriculture, FRC Kazan Scientific Center, Russian Academy of Sciences

*Correspnding author email: i.beilin@ rambler.ru

(recibido/received: 16-July-2020; aceptado/accepted: 19-September-2020)

\begin{abstract}
The article describes the role of Russia in the global gas industry, on the basis of the analysis of the factual data cited, conclusions are drawn about the provision of the economy with the considered minerals, the main problems in managing the supply chains of natural gas and liquefied natural gas are formulated, and innovative ways to solve them are proposed. Based on the fuzzy modeling method, it was shown that the maximum amount of budget revenues from the export duty of Russian natural gas from the main gasbearing regions can almost double. At the same time, the minimum volume in the same case remains virtually unchanged, remaining within $10 \%$. The use of fuzzy modeling in innovation management in the supply chains of Russian natural gas is caused by high volatility in the global commodity markets, both for the underlying asset (in this case, natural gas) and for derivative financial instruments (derivatives). Based on the simplex optimization method, innovation management schemes have been developed in the supply chains of Russian natural gas, taking into account the regional structure of its production. The differences in the economic efficiency of the export duty for the Russian budget between the supply of pipeline natural gas and liquefied natural gas are shown. The author's methods presented in the article can be used as additional innovative tools for making strategic and operational management decisions by industry leaders and public authorities.
\end{abstract}

Keywords: supply chain management, economics, econometrics, innovation management, regional economy, natural gas

\section{RESUMEN}

El artículo describe el papel de Rusia en la industria global del gas, sobre la base del análisis de los datos fácticos citados, se extraen conclusiones sobre la provisión de la economía con los minerales considerados, los principales problemas en la gestión de las cadenas de suministro de gas natural. y se formulan gas natural licuado y se proponen formas innovadoras de solucionarlos. Sobre la base del método de modelado difuso, se demostró que la cantidad máxima de ingresos presupuestarios de los derechos de exportación del gas natural ruso de las principales regiones gasíferas puede casi duplicarse. Al 
mismo tiempo, el volumen mínimo en el mismo caso permanece prácticamente sin cambios, permaneciendo dentro del 10\%. El uso de modelos difusos en la gestión de la innovación en las cadenas de suministro de gas natural ruso se debe a la alta volatilidad en los mercados mundiales de materias primas, tanto para el activo subyacente (en este caso, gas natural) como para los instrumentos financieros derivados (derivados). Sobre la base del método de optimización simplex, se han desarrollado esquemas de gestión de la innovación en las cadenas de suministro de gas natural ruso, teniendo en cuenta la estructura regional de su producción. Se muestran las diferencias en la eficiencia económica del derecho de exportación para el presupuesto ruso entre el suministro de gas natural por tubería y gas natural licuado. Los métodos del autor presentados en el artículo se pueden utilizar como herramientas innovadoras adicionales para la toma de decisiones de gestión estratégica y operativa por parte de líderes de la industria y autoridades públicas.

Palabras clave: gestión de la cadena de suministro, economía, econometría, gestión de la innovación, economía regional, gas natural.

\section{INTRODUCTION}

The Russian Federation has the largest natural gas resource base in the world, including free gas from gas deposits, gas caps forming above oil deposits, as well as gas dissolved in oil. In terms of natural gas production, Russia is second only to the United States, while being its main supplier to the world market. In addition, the country is among the ten largest exporters of liquefied natural gas (LNG). Russian natural gas is characterized by a high $(\sim 98 \%)$ methane content and high calorific value.

In the structure of Russia's fuel balance, gas accounts for about half of the total production of combustible minerals. In the future, gas production in the country may increase, but currently there is only a market for 0.7 trillion cubic meters of gas per year. The production of Russian natural gas consists of production in the actual gas and gas condensate fields, where free gas is produced, production in complex fields where gas can occur both in the form of separate gas deposits and in a gas cap, as well as production of gas dissolved in oil at oil deposits.

In the structure of produced gas for the entire period of its extraction up to the beginning of 2018, free gas (CB) sharply prevails, which accounts for $85.3 \%$; another $7 \%$ is gas cap gas (GS), $7.7 \%$ is gas dissolved in oil. In 2018, an 18-year record for natural gas production was broken in Russia - the annual rate reached 725.4 billion cubic meters, which is 5\% more than in 2017. Annually, about $30 \%$ of the natural gas produced in Russia is exported the rest goes to domestic consumption (Kryukov \& Tokarev, 2018; Kryukov \& Moe, 2018; Noreng, 2006; Shearmur, 2010). Over the past decade, shipments abroad have increased by almost a third. LNG is also supplied to foreign markets, whose sales in 2018 increased by 1.5 times compared to the previous year.

\section{METHODOLOGY}

The main objective of supply chain management is to monitor and interconnect production, distribution and shipment of products and services. This can be done by companies with very good and tight control over domestic stocks, production, distribution, domestic production and sales. Supply chain management mainly integrates supply and demand management. He uses various strategies and approaches to view the entire chain and work effectively at each stage of the chain (The economic contribution of the onshore independent oil and natural gas producers to the U.S. Economy, 2011; Beilin, 2017; Williamson, 2010; Williamson, 2010; Beilin et al., 2019). Each unit involved in the process should strive to minimize costs and help companies improve 
their long-term performance, as well as create value for their stakeholders and customers. This process can also minimize bids by eliminating unnecessary expenses, traffic and handling. It should be noted here that supply chain management and supply chain event management are two different topics that need to be considered. Supply chain event management considers factors that can interrupt the flow of an effective supply chain; possible scenarios are considered and, accordingly, solutions are developed for them.

In this era of globalization, when companies compete with each other to provide consumers with the highest quality products and meet all their requirements, supply chain management plays a very important role (Beilin et al., 2019; Irandoust \& Ericsson, 2004; Barbier, 2003; Kauffman et al., 2018; Sriyakul et al., 2019; Beilin et al., 2019). All companies are highly dependent on an efficient supply chain. The key benefits of supply chain management are:

Develops better customer relations and service, creates better mechanisms for the delivery of goods and services with minimal delays.

Improvises productivity and business functions, minimizes storage and transportation costs.

Minimizes direct and indirect costs, helps in delivering the right products to the right place at the right time

Improves inventory management by supporting the successful completion of stock models on time

Helps companies adapt to the challenges of globalization, economic shocks, broadening consumer expectations and related differences.

Helps companies minimize waste, reduce costs and improve the efficiency of the entire supply chain process.

Develops better customer relations and service, creates better mechanisms for the delivery of goods and services with minimal delays.

Improvises productivity and business functions, minimizes storage and transportation costs minimizes direct and indirect costs.

It helps in delivering the right products to the right place at the right time, improves inventory management, supporting the successful implementation of stock models on time.

Helps companies adapt to the challenges of globalization, economic shocks, broadening consumer expectations and related differences.

Helps companies minimize waste, reduce costs and improve the efficiency of the entire supply chain process.

\section{RESULTS}

The largest buyer of Russian gas is Germany (25\% of exports in 2018), in significant quantities it is also bought by Italy (11\%), Turkey $(10 \%)$, the Republic of Belarus $(8.5 \%)$, France (4\%); in 2017, Slovakia was among the largest importers (6.4\%). Since 2011, gas supplies to Ukraine have been reduced; in 2016, they completely stopped. Domestic natural gas consumption in 2017-2018 grew due to an increase in its production. In 2018, it was estimated at 477 billion cubic meters, in 2017 - 469 billion cubic meters. m For the development of the domestic gas market and the creation of comfortable household conditions for the population, one of the priority areas of the Ministry of Energy of Russia is gasification and gas supply to the constituent entities of the Russian Federation. Gas supplies to Russian consumers are provided by 23 underground gas storages (UGS) owned by PJSC Gazprom. According to data at the beginning of 2019, the total capacity of domestic underground gas storage facilities reached 75 billion cubic meters of gas. 
In 2018, 52 billion cubic meters were selected from Russian UGS facilities. m of gas injected 49.5 billion cubic meters. Transportation of Russian gas to domestic and foreign consumers is carried out through trunk pipelines integrated into the Unified Gas Supply System (UGSS) of Russia. The owner of the gas transmission system (GTS) in the Russian Federation is PJSC Gazprom. As of the end of 2018, the length of its main component reached 172.6 thousand $\mathrm{km}$ (Fig. 4).

At the end of 2019, PJSC Gazprom plans to begin supplying gas to China through the Power of Siberia gas pipeline, the construction of which is being completed in the east of the country (Heil \& Bornemann, 2018; Arize, 2002; Yakupova et al., 2017; Vagizova et al., 2014; Narayan \& Narayan, 2004). A gas pipeline with an annual export capacity of 38 billion cubic meters will pass through the territory of the Irkutsk and Amur regions, the Republic of Sakha (Yakutia).It is also planned to commission the Nord Stream-2 gas pipeline by the end of 2019; its construction is underway as part of the expansion of the Northern Gas Transportation Corridor.

The total annual capacity of the two Nord Stream-2 strings will be 55 billion cubic meters. m, which will double gas supplies to Europe. According to data at the beginning of July 2019, the construction of a gas pipeline with a design length of $2,400 \mathrm{~km}$ along two lines was completed by almost two-thirds. In June 2018, Sweden issued a permit for the construction of the pipeline, but Danish permission was not obtained. In the summer of 2019, the application for the main route in the territorial waters of Denmark was withdrawn. In December 2018, PJSC Gazprom commissioned the second string of the Ukhta-Torzhok-2 gas pipeline with a capacity of 45 billion cubic meters of gas per year and a length of $970 \mathrm{~km}$.

The Ukhta-Torzhok and Ukhta-Torzhok-2 gas pipelines will supply additional gas to the NorthWest region of Russia for gas supply to both domestic and foreign consumers. In addition, these pipelines are an important element of the new gas transportation infrastructure being created for supplying gas to the Nord Stream-2 gas pipeline. To ensure the reliability of gas supply in Turkey, as well as in the countries of South and Southeast Europe, a project is underway to construct the Turkish Stream gas pipeline with an annual design capacity of 31.5 billion cubic meters of gas and a length of $930 \mathrm{~km}$ along two lines. In March 2019, PJSC Gazprom announced the completion of work on connecting the offshore and onshore parts of the pipeline. Its launch is scheduled for the end of 2019. Russia annually imports a small amount of natural gas, mainly from Kazakhstan and Uzbekistan. In 2018, imports amounted to 25.2 billion cubic meters - a third more than in the previous year.

Thus, Russia, thanks to the unique raw material base of high-quality natural gas and active projects for the development of new regions, is the second-largest gas producer in the world and its main exporter. Proved natural gas reserves are estimated in more than 50 countries of the world and as of 01.01.2019 were estimated at 196.9 trillion cubic meters (table. 2). World natural gas production in 2018 amounted to 3,867.9 billion cubic meters (table. 3 ).

Table 2: Proved reserves of free gas in the leading countries of the world. Compiled by the author according to the BP Statistical Review of World Energy

\begin{tabular}{|c|c|c|}
\hline \multirow{2}{*}{ Country } & \multicolumn{2}{|c|}{ Proved reserves } \\
\cline { 2 - 3 } & $\begin{array}{c}\text { Trillion } \\
\text { cubic meters }\end{array}$ & $\begin{array}{c}\text { Share in } \\
\text { world stocks, } \%\end{array}$ \\
\hline USA & 11,9 & 6 \\
\hline Russia & 38,9 & 20 \\
\hline Iran & 31,9 & 16 \\
\hline Canada & 1,9 & 1 \\
\hline Qatar & 24,7 & 12,5 \\
\hline
\end{tabular}




\begin{tabular}{|c|c|c|}
\hline China & 6,1 & 3 \\
\hline Turkmenistan & 19,5 & 10 \\
\hline Other & 62 & 31,5 \\
\hline World & 196,9 & 100 \\
\hline
\end{tabular}

Table 3. Production of free gas in the leading countries of the world Compiled by the author according to the BP Statistical Review of World Energy

\begin{tabular}{|c|c|c|c|}
\hline \multirow{2}{*}{ Country } & \multicolumn{3}{|c|}{ Production in 2018 } \\
\cline { 2 - 4 } & $\begin{array}{c}\text { Billion cubic } \\
\text { meters min } \\
\text { year }\end{array}$ & $\begin{array}{c}\text { Million } \\
\text { tons } \\
\text { TOE }\end{array}$ & $\begin{array}{c}\text { Share in the } \\
\text { world } \\
\text { production } \\
\% \text { (TOE) }\end{array}$ \\
\hline USA & 831,8 & 715,2 & 21,5 \\
\hline Russia & 669,5 & 575,6 & 17,3 \\
\hline Iran & 239,5 & 205,9 & 6,2 \\
\hline Canada & 184,7 & 152,7 & 4,6 \\
\hline Qatar & 175,5 & 150,9 & 4,5 \\
\hline China & 161,5 & 138,9 & 4,2 \\
\hline Turkmenistan & 61,5 & 52,9 & 1,6 \\
\hline Other & 1543,9 & 1333,7 & 40,1 \\
\hline World & 3867,9 & 3325,8 & 100 \\
\hline
\end{tabular}

\section{DISCUSSION AND CONCLUSION}

Since 2011, the United States has been the undisputed world leader in gas production. Since then, gas production in the country has grown by $35 \%$ and in 2018 amounted to 831.8 billion cubic meters. The driver of growth was the active development of shale gas fields (primarily the Marcellus and Utica basins), whose share in production has been growing from year to year and currently stands at about $60 \%$. After inclusion of shale gas reserves and major gas shale discoveries in the statistics, the structure of US natural gas reserves has fundamentally changed. Shale gas accounts for about $60 \%$ of US reserves, and traditional gas accounts for no more than a third. About $4 \%$ of the reserves are coal bed methane.

In recent years, in parallel with the growth of gas production, its export from the USA has been growing rapidly. Since 2014, more than one and a half times - from 42.3 to 67.6 billion cubic meters - gas supplies to Mexico and Canada increased. During this time, more than 70 times from 0.4 to 28.4 billion cubic meters - LNG export increased; as a result, the United States ranked fourth in the world for LNG supplies to the global market. At the same time, the United States remains a major importer of natural gas, which comes from Canada through pipelines. The remaining countries are significantly behind the leaders in terms of natural gas production.

The third place in the world ranking (after the USA and Russia) since 2014 is occupied by Iran, whose annual production over this period has grown by more than $30 \%$ - from 183.1 to 239.5 billion cubic meters. m. In 2018, Canada took the fourth place, which in 2017 overtook Qatar by 0.6 billion cubic meters. m, moving him to fifth position. At the same time, Qatar is the world's largest producer and exporter of LNG: in 2018, its share in world supplies amounted to $24 \%$. The moratorium on increasing gas production in the country, lifted in April of this year, creates conditions for its active growth (Arize \& Bahmani-Oskooee, 2018; Beilin et al., 2019; Ahec Šonje et al., 2010; Romeijn et al., 2007; Beilin et al., 2019). China is actively increasing production: in 2018, according to the State Statistical Office of China, it increased by $8 \%$ compared to the previous year. In Turkmenistan, the volumes of gas produced have been 
declining since 2016. The reason for this was the cessation of supplies to Russia and their reduction to Iran by almost 7\%; even an increase in exports to China could not rectify the situation.

World natural gas consumption will grow amid a general increase in energy consumption, which, according to the forecasts of the International Energy Agency, will increase by $15 \%$ by 2035 relative to the level of 2018. Being an environmentally friendly and economically attractive fuel, natural gas is actively competing with other its fossil species - oil and coal (Al-Gwaiz et al., 2016; Geunes et al., 2016; Miranda \& Garrido, 2009; Olamade \& Oni, 2016).

The bulk of energy consumption will be provided by Asian countries in addition, an increase in consumption is expected in South America, the Middle East, and Africa.

The price of Russian gas is fully correlated with oil prices. Between 2012 and 2016 its average export value has more than halved - from \$ 348.3 to \$ 157 per 1,000 cubic meters. m. In 2017, with rising oil prices, gas prices rose again; as a result, according to the results of the year, it went up by $15.8 \%$ compared to 2016 . In 2018 , the trend continued - the price increased by another $22.6 \%$. However, even this did not allow her to return to the crisis level of 2009.

In 2018, 1983 fields were developed for gas in Russia, while more than $60 \%$ of Russian gas production is provided by only six of them: Urengoyskoye, Zapolyarnoye, Bovanenkovskoye, Yamburgskoye, Yurkharovskoye and Yuzhno-Russkoye. The Urals Federal District remains the leader in the production of free gas (including gas) in Russia, which in 2018 ensured $84 \%$ of domestic gas production. Here, in the Nadym-Pur-Tazovsky district (NTRD) of the West Siberian oil and gas province in the Yamalo-Nenets Autonomous Okrug (YNAO), there are unique oil and gas condensate fields, including the most productive in the country: Urengoy, Yamburg, Zapolyarnoye, South Russian. For many years, they developed Cenomanian deposits of relatively simple geological structure, containing easily recoverable "dry" gas. The degree of depletion of the main gas horizon is growing every year in 2018 the Cenomanian deposits provided no more than two-thirds of the NTRP gas production (Pillay, 2014; Kloyer et al., 2019; Flynn et al., 2016).

The gas reserves of other oil and gas complexes of the NTRP are mostly difficult to recover. To maintain gas production in Russia, a new gas production cluster is being formed on the Yamal Peninsula. In 2018, production was carried out at the Bovanenkovo oil and gas condensate field and amounted to 87.4 billion cubic meters.

After reaching the planned capacity of 140 billion cubic meters of gas, this field will become the leader of Russian gas production. The Khanty-Mansi Autonomous Okrug-Ugra (Khanty-Mansi Autonomous Okrug-Ugra) in 2018 provided almost $1.8 \%$ of the total gas production (free gas + gas caps) in Russia. The main volume was extracted from the gas caps of the Samotlor, Lyantorsky and Van Yegansky oil and gas fields. In other regions of Russia, gas production is carried out in much smaller volumes - in 2018 their total production amounted to 108.4 billion cubic meters or $16 \%$ of the Russian.

In the Volga Federal District, almost the entire volume of gas production is provided by the Orenburg Region, where the unique Orenburg oil and gas condensate field is being developed. In 2018, it produced 13.8 billion cubic meters of free gas. The advantage of this field is its location near important industrial centers of the Urals and the Volga region, the disadvantage is the presence of a large number of by-products in the gas, which requires preliminary cleaning. The field is at a late stage of development, the depletion of reserves of categories $\mathrm{A}+\mathrm{B} 1$ as of 01.01.2018 was $67.7 \%$.

The management of innovations in the supply chains of Russian natural gas taking into account the regional structure of its production can be expressed using the theory of fuzzy logic. Figures 2 
and 3 show a way to increase budget revenues from export duties from $40 \%-50 \%$ to $45 \%-95 \%$. At the same time, the lower limit of profitability remains virtually unchanged and remains within $5 \%-10 \%$.

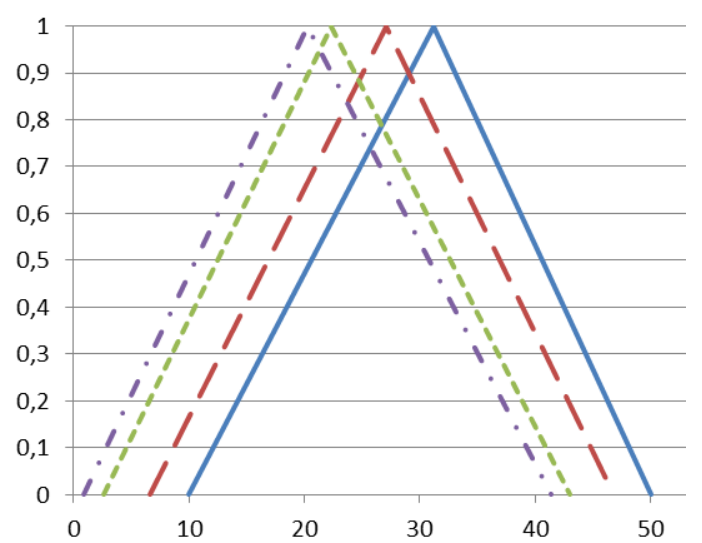

Figure. 2: Dependence of budget revenues on the export duty of Russian natural gas, taking into account the regional structure of its production under the existing situation

Compiled by the author

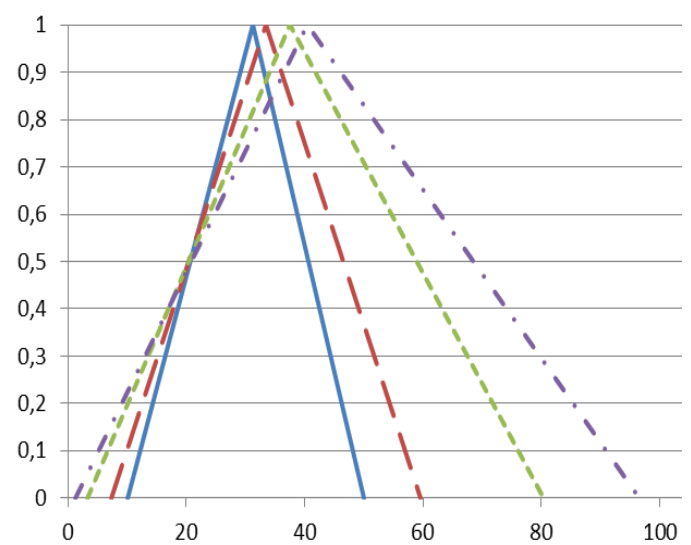

Figure. 3: Dependence of budget profitability on the export duty of Russian natural gas, taking into account the regional structure of its production while managing innovations in supply chains Compiled by the author

Options for optimizing innovation management in the supply chains of Russian pipeline natural gas and LNG, taking into account the regional structure of production, are presented in Fig. 4, 5. 


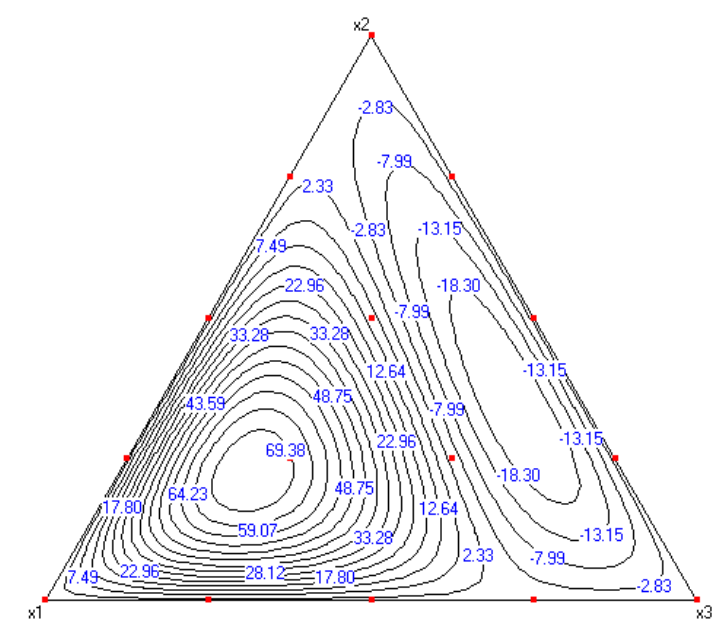

Figure. 4: Optimization scheme for innovation management in the supply chains of Russian pipeline natural gas, taking into account the regional structure of its production

Compiled by the author

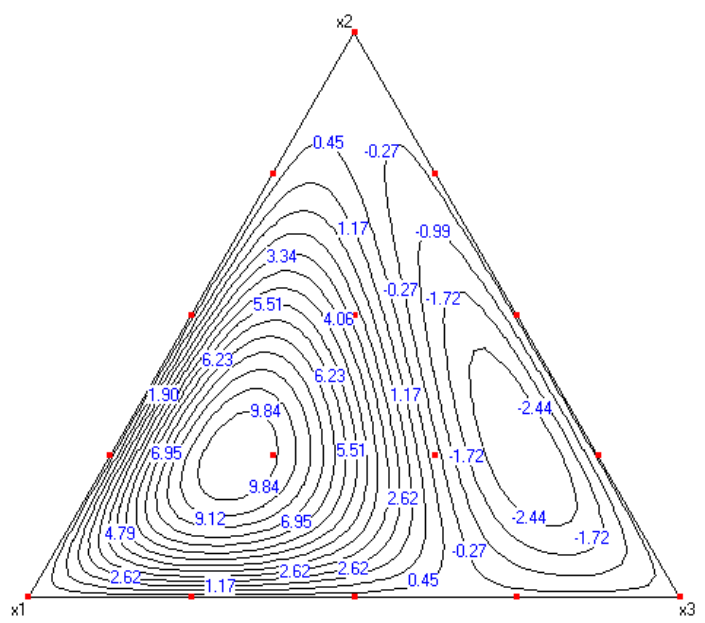

Figure. 5: Optimization scheme of innovation management in the supply chains of Russian LNG, taking into account the regional structure of its production

Compiled by the author

Using a new approach based on simplex optimization allows us to create an innovation management scheme in the supply chains of Russian pipeline natural gas, taking into account the regional structure of its production, which shows the greatest economic efficiency up to 69 billion rubles. in the form of an export duty with the ratio of the main oil and gas regions in exports (Yamal-Nenets Autonomous Okrug (x1), Khanty-Mansi Autonomous Okrug (x2) and Orenburg Oblast (x3)) in the region of 60\%: 30\%: 10\%. Innovation management in the supply chains of Russian LNG based on the presented method allows reaching 9.84 billion rubles. for the same regions (Yamal-Nenets Autonomous Okrug (x1), Khanty-Mansi Autonomous Okrug (x2) and Orenburg Oblast (x3)), and their ratio is shifted to the region of about 50\%: $25 \%: 15 \%$.

\section{ACKNOWLEDGEMENTS}

The work is performed according to the Russian Government Program of Competitive Growth of Kazan Federal University. 
The article was prepared based on the results of research conducted within the framework of the state task under the leadership of the Federal Agency of Scientific Organizations of Russia, with the registration number: AAAA-A18-118031390148-1.

\section{REFERENCES}

Ahec Šonje, A., Podobnik, B., \& Vizek, M. (2010). Long-run relationship between exports and imports in transition European countries. Ekonomski pregled, 61(1-2), 3-18.

Al-Gwaiz, M., Chao, X., \& Romeijn, H. E. (2016). Capacity expansion and cost efficiency improvement in the warehouse problem. Naval Research Logistics (NRL), 63(5), 367-373.

Arize, A. C. (2002). Imports and exports in 50 countries: tests of cointegration and structural breaks. International Review of Economics \& Finance, 11(1), 101-115.

Arize, A. C., \& Bahmani-Oskooee, M. (2018). Do Imports and Exports Adjust Nonlinearly? Evidence from 100 Countries. Global Economy Journal, 18(1).

Beilin, I. L. (2017). Economic optimization in chemical enterprises. International Journal of Economic Perspectives, 11(4), 670-677.

Beilin, I. L., Khomenko, V. V., \& Kalenskaya, N. V. (2019). Institutional aspects of the cluster development of the regional economic system. Humanities \& Social Sciences Reviews, 7(6), 192-196.

Beilin, I. L., Khomenko, V. V., \& Kalenskaya, N. V. (2019). The Stability of the Regional Economic System Based on the Innovative Development of the Petrochemical Cluster. Academic Journal of Interdisciplinary Studies, 8(4), $140-140$.

Beilin, I. L., Khomenko, V. V., Kalenskaya, N. V., \& Solntseva, A. A. (2018). The Significance of the Resource Intensity of the Regional Economy the Development of the Oil and Gas Chemical Complex. The Journal of Social Sciences Research, 328-332.

Beilin, I. L., Khomenko, V. V., Kalenskaya, N. V., \& Solntseva, Đ. Đ. (2018). Analysis of the Functioning of the Regional Oil and Gas Chemical Complex and the Formation of the Region's Resource Potential. The Journal of Social Sciences Research, 245-249.

Beilin, I., Homenko, V., \& Aleeva, D. (2019). Digital modeling of economic processes and supply chain management in the formation of cooperative relations in the petrochemical cluster of the region. SCOPUS205137712019-8-4-SID85071558090.

Beilin, I., Homenko, V., \& Aleeva, D. (2019). The development of the school of spatial analysis of W. Isard on the basis of economic and supply chain management models of the petrochemical and chemical production cluster. SCOPUS20513771-2019-8-4-SID85071558498.

Beilin, I., Khomenko, V., \& Kalenskaya, N. (2019). Improving the management of the industrial development of the region in the context of the integration of enterprises of petrochemical complex. SCOPUS-2019-11-8SID85073421729.

Barbier, E. B. (2003). The Role of Natural Resources in Economic Development. Australian. Economic Papers, 253272. doi: 10.1111/1467-8454.00198.

Flynn, B. B., Koufteros, X., \& Lu, G. (2016). On theory in supply chain uncertainty and its implications for supply chain integration. Journal of Supply Chain Management, 52(3), 3-27.

Geunes, J., Romeijn, H. E., \& van den Heuvel, W. (2016). Improving the efficiency of decentralized supply chains 
with fixed ordering costs. European Journal of Operational Research, 252(3), 815-828.

Heil, S., \& Bornemann, T. (2018). Creating shareholder value via collaborative innovation: the role of industry and resource alignment in knowledge exploration. R\&D Management, 48(4), 394-409.

Irandoust, M., \& Ericsson, J. (2004). Are imports and exports cointegrated? An international comparison. Metroeconomica, 55(1), 49-64.

Kauffman, S., Pathak, S. D., Sen, P. K., \& Choi, T. Y. (2018). Jury rigging and supply network design: Evolutionary "Tinkering" in the presence of unknown-unknowns. Journal of Supply Chain Management, 54(1), 51-63.

Kloyer, M., Helm, R., \& Aust, C. (2019). Determinants of moral hazard in research and development supply relations: Empirical results beyond the agency-theory explanation. Managerial and Decision Economics, 40(1), 6478.

Kryukov, V. A., \& Tokarev, A. N. (2018). Spatial Dynamics of the Oil and Gas Field Services Sector: Global Trends and Lessons for Russia. Regional Research of Russia, 8(3), 248-257.

Kryukov, V., \& Moe, A. (2018). Does Russian unconventional oil have a future?. Energy Policy, 119, 41-50.

Miranda, P. A., \& Garrido, R. A. (2009). Inventory service-level optimization within distribution network design problem. International Journal of production economics, 122(1), 276-285.

Narayan, P. K., \& Narayan, S. (2004). Is there a long-run relationship between exports and imports? Evidence from two Pacific Island Countries. Economic Papers: A journal of applied economics and policy, 23(2), 152-164.

Noreng, O. (2006). Crude Power: Politics and the Oil Market, London, LB. Tauris Co.

Olamade, O., \& Oni, O. (2016). Exports and Imports Cointegration: Further Evidence from the ECOWAS. American Journal of Economics, 6 (4), 181-188.

Pillay, S. (2014). The long run relationship between exports and imports in South Africa: Evidence from cointegration analysis. International Journal of Economics and Management Engineering, 8(6), 1976-1979.

Romeijn, H. E., Shu, J., \& Teo, C. P. (2007). Designing two-echelon supply networks. European Journal of Operational Research, 178(2), 449-462.

Shearmur, R. (2010). Space, place and innovation: a distance-based approach. The Canadian Geographer/Le Geographe canadien, 54(1), 46-67.

Sriyakul, T., Umam, R., \& Jermsittiparsert, K. (2019). Internal Supply Chain Integration and Operational Performance of Indonesian Fashion Industry Firms: A Supplier to Buyer Approach. Humanities and Social Sciences Reviews, 7(2), 479-486.

The economic contribution of the onshore independent oil and natural gas producers to the U.S. Economy. (2011). USA: IHS Global Insight -63 p.

Vagizova, V., Homenko, V., \& Akhmetova, G. (2014). The Volga region banking and real sectors interaction cluster initiatives. Investment management and financial innovations, (11, Iss. 4 (spec. iss.)), 1334-141.

Williamson, O. E. (2010). Transaction cost economics: The natural progression. American Economic Review, 100(3), 673-90.

Williamson, O. E. (2010). Transaction cost economics: the origins. Journal of Retailing, 86(3), 227-231.

Yakupova, N. M., Levachkova, S. J., Kadochnikova, E. I., \& Beilin, I. L. (2017). Measurement of cost factors: Evidence from trading companies. International Journal of Economic Perspectives, 11(4), 794-802.

Short biography of the author: 
Beilin I. L .: education Kazan (Volga) Federal University, economist, diploma with honors. PhD, Associate Professor, Department of Territorial Economics, Institute of Management, Economics and Finance. The area of scientific interests is economics and management of the region's petrochemical complex. 